\title{
A "two-hit" (chemo)therapy to improve checkpoint inhibition in cancer
}

\author{
Paolo Falvo ${ }^{1 *}$, Stefania Orecchioni ${ }^{1 *}$, Alessandro Raveane ${ }^{1 *}$, Giulia Mitola ${ }^{1}$, \\ and Francesco Bertolini ${ }^{1}$ \\ ${ }^{1}$ Laboratory of Hematology-Oncology, European Institute of Oncology IRCCS, Milan 20141, Italy \\ * Contributed equally to this work
}

Correspondence to: Francesco Bertolini, email: francesco.bertolini@ieo.it

Keywords: anti-PD-1; immunotherapy; breast cancer; lymphoma; chemotherapy; T-cell therapy

Received: March 30, 2021

Accepted: April 16, 2021

Published: May 7, 2021

Copyright: ( 2021 Falvo et al. This is an open access article distributed under the terms of the Creative Commons Attribution License (CC BY 3.0), which permits unrestricted use, distribution, and reproduction in any medium, provided the original author and source are credited.

In the last decade, anti-PD-1 and anti-PD-L1 checkpoint inhibitors (CIs) have demonstrated to be clinically active as a single agent in several types of solid tumors and hematological malignancies. However, the clinical benefit is observed only in a fraction of patients and, in the majority of cases, only for a limited period of time [1]. These observations, along with the evidence of multilayered complexity in cancer cells, cancer microenvironment and anti-cancer immunity, have promoted preclinical and clinical studies with combinatorial drugs aimed at improving CI activity by re-shaping the immune system before and during $\mathrm{CI}$ administration [2].

Chemotherapeutics are known to have profound effects over several myeloid, innate, helper and effector immune cell subsets [3]. As CI clinical activity is dependent upon a coordinated activity between tumor antigen processing by some myeloid antigenpresenting cells (APCs), and cancer cell targeting by helper and effector T cells [4], we investigated in vivo in immunocompetent murine models of triple negative breast cancer (TNBC) and B-cell lymphoma the effects of different types and dosages of chemotherapeutics over the immune cell orchestra.

Two main findings emerged: first, we observed that vinca alcaloids $(\mathrm{V})$, at low dosages, can generate and activate new APCs. Secondly, we found that intermitted, medium dosage cyclophosphamide (140 mg/ $\mathrm{Kg}$ every 6 days, C140) can generate new CD3+CD4+ and $\mathrm{CD} 3+\mathrm{CD} 8+\mathrm{T}$ cell clones. In our models, a "twohit" approach (V plus C140) significantly improved CI preclinical activity against local and disseminated neoplastic growth [5-6].

Our models included mice with neoplastic lesions showing an immune infiltrate predominantly including lymphoid cells and others with and an immune infiltrate with high proportions of myeloid cells. In both cases, antibody-mediated depletion of $\mathrm{CD} 3+\mathrm{CD} 4+$ or of $\mathrm{CD} 3+\mathrm{CD} 8+\mathrm{T}$ cells abrogated the preclinical efficacy of the V plus C140 plus CI combinatorial therapy. These data suggest that anti-cancer activity was largely related to these immune T cells [6].

Single-cell transcriptome analysis of $>50,000$ intratumoural immune cells, after V plus C140 and CI combinatorial therapy, showed a gene signature suggestive of a change resulting from exposure to a mitogen, ligand, or an antigen for which it is specific, as well as APC-toT-cell adhesion [6]. This transcriptional program also significantly increased the number of intratumoural $T c f 1+$ stem-like CD8+ T-cells [7] and altered the balance between terminally and progenitor exhausted T-cells, favoring the latter [6]. The proposed mechanism of $\mathrm{V}$ plus C140 and CI combinatorial therapy is showed in (Figure 1).

As V and C140 dosages found to significantly improve CI preclinical activity are suitable for a combinatorial use in cancer patients, clinical trials in TNBC and B-cell lymphoma are now planned to confirm the efficacy of this "two-hit" plus CI therapy. It will be of interest to investigate in enrolled patients a number of emerging candidate biomarkers of immune cell activation, including: a) APC activation patterns; b) the generation of new TCF1+ stem-like CD8+ T-cells; c) CXCL13 and CCR5 overexpressing, neo-antigen reactive CD8+ $\mathrm{T}$ cells [8]; d) newly generated IFN- $\gamma$-expressing resident memory $\mathrm{T}$ cells [9]; e) pre-treatment values of senescent CD28CD57+KLGR1+CD8+ T cells [10]; and f) post-treatment values of proliferating PD- $1+\mathrm{CD} 8+\mathrm{T}$ cells [11]. The goal of such a therapy, in fact, is the generation of a long-lasting anti-tumor immunity in treated cancer patients.

\section{ACKNOWLEDGEMENTS}

Supported by the Italian Association for Cancer Research (AIRC) and the Italian Ministry of Health. 


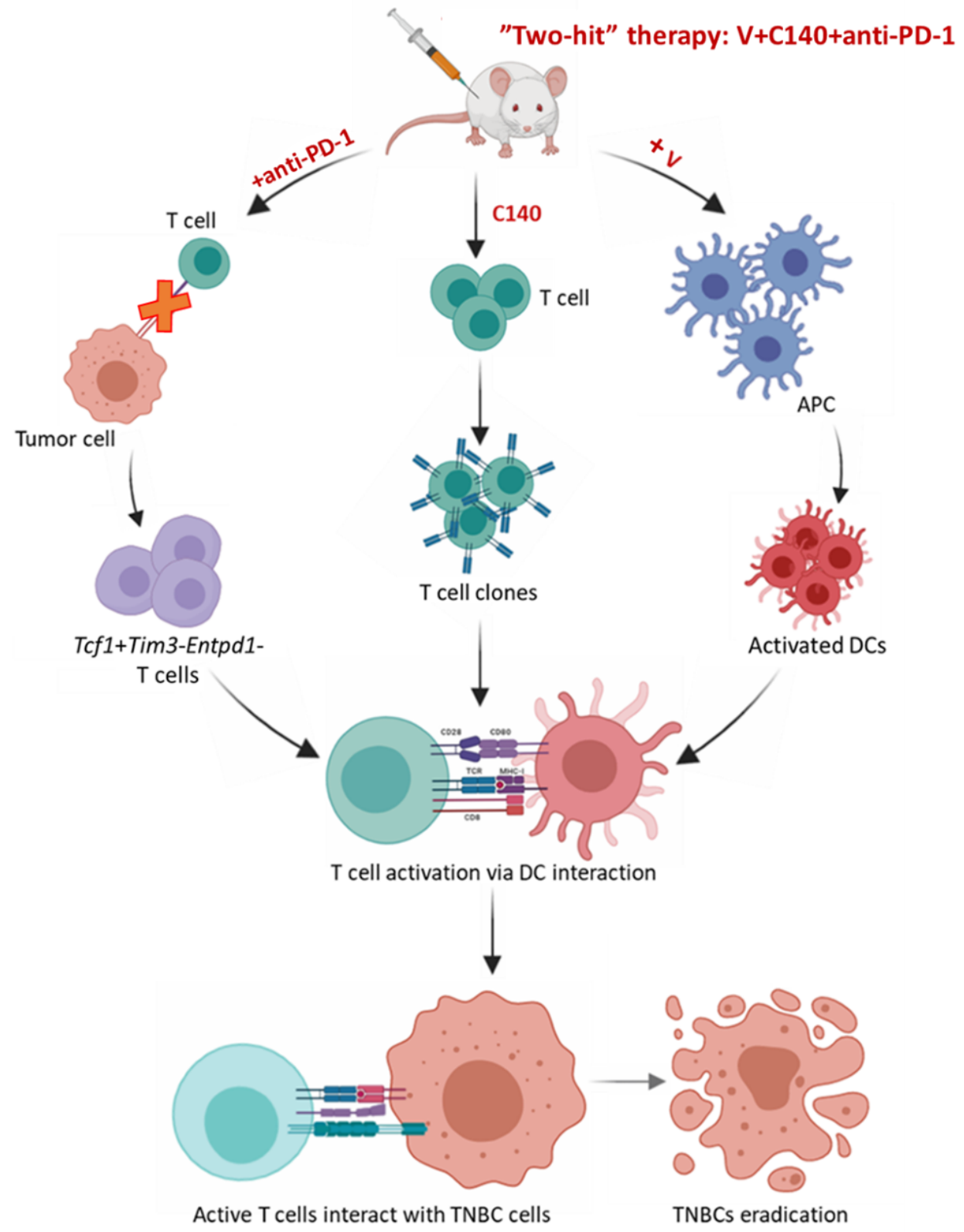

Figure 1: Graphical abstract of the preclinical effects of the "two hit" therapy (V plus C140 and anti-PD1) over APC, T and cancer cells in TNBC models. "The image was generated using BioRender software (https://biorender.com/)" 


\section{CONFLICTS OF INTEREST}

The authors declare no potential conflicts of interest.

\section{REFERENCES}

1. Kalbasi A, Ribas A. Tumour-intrinsic resistance to immune checkpoint blockade. Nat Rev Immunol. 2020; 20:25-39. https://doi.org/10.1038/s41577-019-0218-4. PMID:31570880

2. Upadhaya S, Neftelino ST, Hodge JP, Oliva C, Campbell JR, Yu JX. Combinations take centre stage in PD1/PDL1 inhibitor clinical trials. Nat Rev Drug Discov. 2021; 20:168-69. https://doi.org/10.1038/d41573-020-00204-y. PMID:33177720

3. Galluzzi L, Humeau J, Buqué A, Zitvogel L, Kroemer G. Immunostimulation with chemotherapy in the era of immune checkpoint inhibitors. Nat Rev Clin Oncol. 2020; 17:725-41. https://doi.org/10.1038/s41571-020-0413-Z. PMID:32760014

4. Tang H, Liang Y, Anders RA, Taube JM, Qiu X, Mulgaonkar A, Liu X, Harrington SM, Guo J, Xin Y, Xiong Y, Nham K, Silvers W, et al. PD-L1 on host cells is essential for PD-L1 blockade-mediated tumor regression. J Clin Invest. 2018; 128:580-88. https://doi.org/10.1172/ JCI96061. PMID:29337303

5. Orecchioni S, Talarico G, Labanca V, Calleri A, Mancuso P, Bertolini F. Vinorelbine, cyclophosphamide and 5-FU effects on the circulating and intratumoural landscape of immune cells improve anti-PD-L1 efficacy in preclinical models of breast cancer and lymphoma. Br J Cancer. 2018; 118:1329-36. https://doi.org/10.1038/s41416-018-0076-Z. PMID:29695766

6. Falvo P, Orecchioni S, Hillje R, Raveane A, Mancuso P, Camisaschi C, Luzi L, Pelicci P, Bertolini F. Cyclophosphamide and vinorelbine activate stem-like CD8+ $\mathrm{T}$ cells and improve anti-PD-1 efficacy in triplenegative breast cancer. Cancer Res. 2021; 81:685-97. https://doi.org/10.1158/0008-5472.CAN-20-1818. PMID:33268528

7. Siddiqui I, Schaeuble K, Chennupati V, Fuertes Marraco SA, Calderon-Copete S, Pais Ferreira D, Carmona SJ, Scarpellino L, Gfeller D, Pradervand S, Luther SA, Speiser DE, Held W. Intratumoral Tcf1+PD-1+CD8+ T Cells with Stem-like Properties Promote Tumor Control in Response to Vaccination and Checkpoint Blockade Immunotherapy. Immunity. 2019; 50:195-211.e10. https://doi.org/10.1016/j. immuni.2018.12.021. PMID:30635237

8. Litchfield K, Reading JL, Puttick C, Thakkar K, Abbosh C, Bentham R, Watkins TB, Rosenthal R, Biswas D, Rowan A, Lim E, Al Bakir M, Turati V, et al. Meta-analysis of tumor- and $\mathrm{T}$ cell-intrinsic mechanisms of sensitization to checkpoint inhibition. Cell. 2021; 184:596-614.e14. https:// doi.org/10.1016/j.cell.2021.01.002. PMID:33508232

9. Han J, Zhao Y, Shirai K, Molodtsov A, Kolling FW, Fisher JL, Zhang P, Yan S, Searles TG, Bader JM, Gui J, Cheng $\mathrm{C}$, Ernstoff MS, et al. Resident and circulating memory $\mathrm{T}$ cells persist for years in melanoma patients with durable responses to immunotherapy. Nature Cancer. 2021;2:300311. https://doi.org/10.1038/s43018-021-00180-1.

10. Ferrara R, Naigeon M, Auclin E, Duchemann B, Cassard L, Jouniaux JM, Boselli L, Grivel J, Desnoyer A, Mezquita L, Texier M, Caramella C, Hendriks L, et al. Circulating T-cell Immunosenescence in Patients with Advanced Non-small Cell Lung Cancer Treated with Single-agent PD-1/PD-L1 Inhibitors or Platinum-based Chemotherapy. Clin Cancer Res. 2021; 27:492-503. https://doi.org/10.1158/1078-0432. CCR-20-1420. PMID:32887723

11. Kim KH, Cho J, Ku BM, Koh J, Sun JM, Lee SH, Ahn JS, Cheon J, Min YJ, Park SH, Park K, Ahn MJ, Shin EC. The First-week Proliferative Response of Peripheral Blood PD1+CD8+ T Cells Predicts the Response to Anti-PD-1 Therapy in Solid Tumors. Clin Cancer Res. 2019; 25:2144-54. https:// doi.org/10.1158/1078-0432.CCR-18-1449. PMID:30647082 